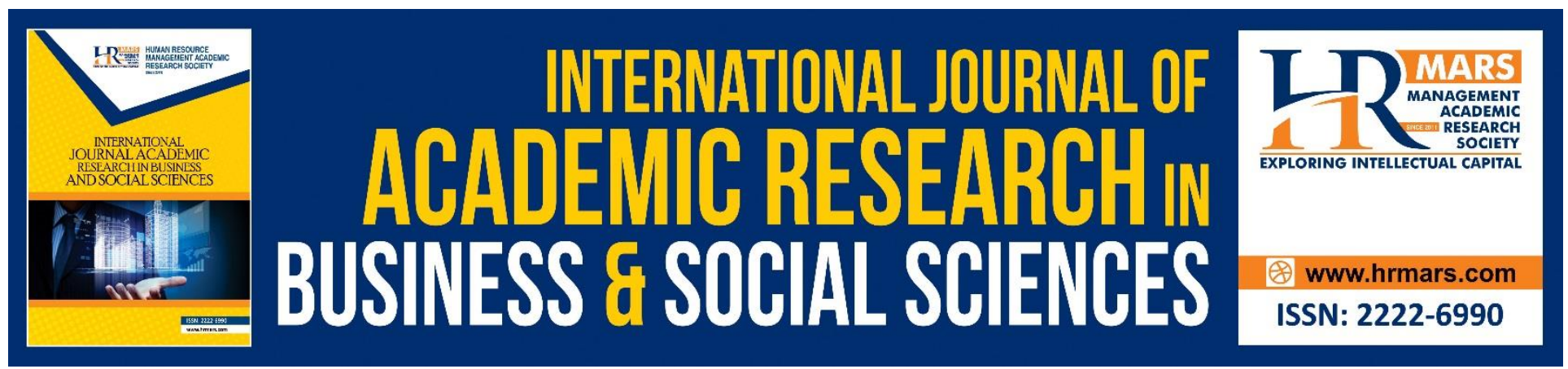

\title{
Urban Poverty and Housing: Social Work Issues
}

\begin{abstract}
Y.M. Haizzan, R. B. Radin Firdaus, Mohamad Shaharudin Samsurijan, Abdul Rais Abdul Latiff, Paramjit Singh Jamir Singh, Mohd Hafiidz Jaafar, Kumarashwaren Vadevelu
\end{abstract}

To Link this Article: http://dx.doi.org/10.6007/IJARBSS/v8-i9/4684

DOI: $\quad 10.6007 /$ IJARBSS/v8-i9/4684

Received: 08 August 2018, Revised: 16 Sept 2018, Accepted: 29 Sept 2018

Published Online: 13 October 2018

In-Text Citation: (Haizzan et al., 2018)

To Cite this Article: Haizzan, Y. M., Firdaus, R. B. R., Samsurijan, M. S., Latiff, A. R. A., Singh, P. S. J., Jaafar, M. H., \& Vadevelu, K. (2018). Urban Poverty and Housing: Social Work Issues. International Journal of Academic Research in Business and Social Sciences, 8(9), 1111-1118.

Copyright: (C) 2018 The Author(s)

Published by Human Resource Management Academic Research Society (www.hrmars.com)

This article is published under the Creative Commons Attribution (CC BY 4.0) license. Anyone may reproduce, distribute, translate and create derivative works of this article (for both commercial and non-commercial purposes), subject to full attribution to the original publication and authors. The full terms of this license may be seen at: http://creativecommons.org/licences/by/4.0/legalcode

Vol. 8, No. 9, September 2018, Pg. 1111 - 1118 http://hrmars.com/index.php/pages/detail/IJARBSS JOURNAL HOMEPAGE

Full Terms \& Conditions of access and use can be found at http://hrmars.com/index.php/pages/detail/publication-ethics 


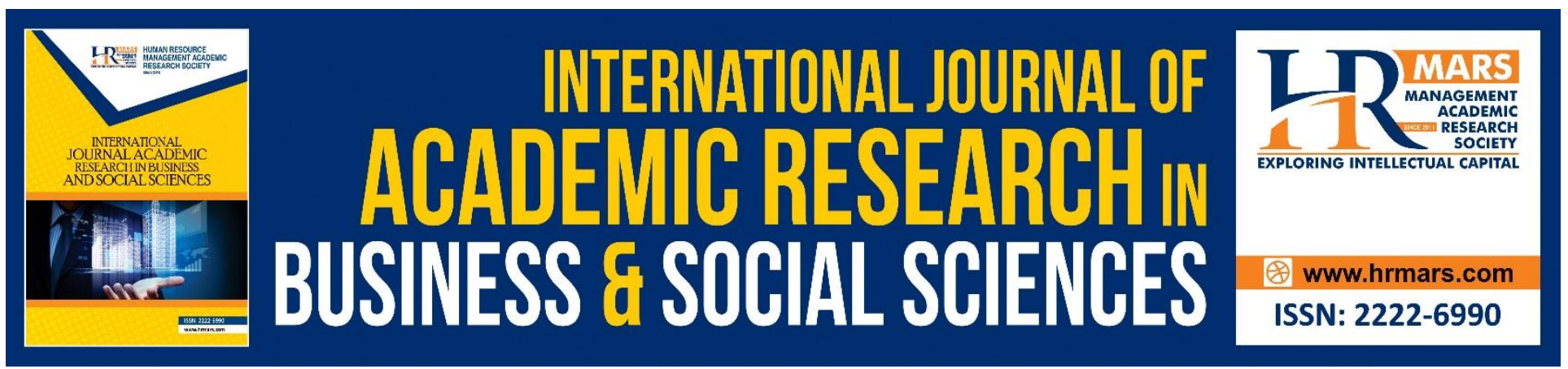

\title{
Urban Poverty and Housing: Social Work Issues
}

\author{
Y.M. Haizzan ${ }^{1 *}$, R. B. Radin Firdaus ${ }^{1}$, Mohamad Shaharudin \\ Samsurijan ${ }^{1}$, Abdul Rais Abdul Latiff ${ }^{1}$, Paramjit Singh Jamir Singh ${ }^{1}$, \\ Mohd Hafiidz Jaafar ${ }^{2}$, Kumarashwaren Vadevelu ${ }^{3}$ \\ ${ }^{1 *}$ School of Social Sciences, Universiti Sains Malaysia, 11800 Pulau Pinang, Malaysia. \\ ${ }^{2}$ School of Industrial Technology, Universiti Sains Malaysia, 11800 Pulau Pinang, Malaysia. \\ ${ }^{3}$ Prince of Songkla University, 94000 Pattani, Thailand
}

\begin{abstract}
The objective of this paper is to review the major concern on urban poverty, housing needs and housing issues in Penang, Malaysia. Issues on home ownership, policies, and program had been addresses. In addition, some feedback from the high level person related to housing industries had been reviewed, analyzed and been discussed in this paper too. The study found that a large number of respondents from the target group still do not have home ownership of their own, and there is a significant relationship between monthly incomes with home ownership by the target group. From the perspective of social work, a better policy, and better program need to be implement. This is important in order to ensure the revolution of housing development in Penang will fit in the Penangites for a short term and even for the long term period.
\end{abstract}

Keywords: Urban poverty, Social Work, Housing, Home Ownership, Social Policy

\section{Urban Poverty}

Poverty can be measured by normative boundaries that cause feelings of inadequacy compared and lead distribution to the poor and the rich (Chamhuri Siwar, 1994, Haflah Piei, 1988). While urban poverty is divided into absolute poverty, relative poverty and extreme poverty. Absolute poverty is a condition of households who are unable to achieve an income that can cover basic their needs. Relative poverty is also a group income inequality in a society and a condition of a household who are unable to reach at least half of the Poverty Line Income (PLI) to cover basic living. Socially, poverty is said to be a very poor in social condition, such as the provision of insufficient health needs and insufficient minimum basics needs and source of information (Narrayan-Parker, 1997).

PGK set by the government of RM 350 in 1989 and RM405 in 1993, which did not distinguish urban and rural areas. This is due to the area has a different cost of living (Mohd Taib Dora, 2000; Ragayah, 2006). The poverty line in the country at this point is set at income levels below RM720 per month (Borneo Post, 2010). Urban poverty is at $2.4 \%$ in 1985 and decreased to $0.3 \%$ in 2002 
(Chamsuri Siwar, 2005). According to the Minister in the Prime Minister's Department Tan Sri Nor Mohamed (at the time), the poverty rate among the population living in urban areas in the country is around $2 \%$ and extreme poverty was at $0.3 \%$.

Statistics shows that $7 \%$ of the country's population lives in urban areas (Utusan Malaysia, 2010). Urban poverty is a serious issue with the number of households in the city is increasing (Chamhuri Siwar, 2005). Urban areas particularly housing issues, especially the problem of housing in slum areas and residents of low cost is a common problem faced by the poor and low-income families in the city. The active group is estimated at $47.7 \%$, ie $35.0 \%$ of men and $12.7 \%$ women from 158 families (Mohd. Taib Dora, 2000). In addition, the group remains categorized as those who are physically handicapped, elderly and infirm prolonged suffering. Disability factor is one of the reasons of poverty (Townsend, 1979).

\section{House Poverty}

The definition of house poverty cannot be stated precisely because of it is subjective term. However, poverty is usually associated with a lack of income, the hardship and the inability of individuals and households to meet basic daily needs and in the case of ownership of a house, particularly for middleincome earners. Between the definition of poverty by the experts, Specker (1993) states that poverty included; (1) Lack of physical facilities for a normal life, (2) Harassment and high health risk, (3) A security risk and ability economic and social life are closely related thereto, (4) Lack of income resulting hardships and (5) Lack of social life which can be demonstrated by social alienation, marginalization in the political process, and the low quality of educators.

While Charles Booth defines poverty as someone living in difficult conditions to meet the needs of adequate living (Holman, 1978). This definition describes the relationship between poverty and the inability to meet the minimum requirements for ownership of housing or maintaining physical efficiency to meet basic needs. Poverty is defined as a condition that income insecurity, lack of quality basic needs, housing and disability in the ownership of productive assets such as maintaining good health, dependency and lack of help, their antisocial behaviour (anti-social behaviour), lack of network resources to get a life the good, the lack of infrastructure and remoteness, as well as disability and separateness (Poli, 1993).

Urban poverty is said to occur because of the poor less exposure to resources and basic amenities such as housing and education, low income and have had to deal with the flow of rising prices, and lack of knowledge and information about government assistance (Trends 1980: 10 -12; Mohd Taib Dora, 2000). This situation makes the occurrence of so-called 'social exclusion' is believed to be the main reason for the existence of poverty. If these issues can be overcome in marginalization, urban poverty is believed to be triumph over (Mohd Taib Dora, 2000).

In the meantime, the housing is defined as a series of homes that are consolidated in a residential area. In the housing element, there are several sub-elements with all its physical facilities such as the provision of clean drinking water, a place of worship, landfills, there is electricity, telephone, roads connecting residential areas to the main road, and functioning as it should. In residential areas, people live in groups and carry out social activities with each other.

The concept is said to be healthy when the house; (1) Meets the basic physical needs such as lower temperature than the air outside of the house, adequate light, ventilation, comfortable, and 
noise level are between 45-55 dB.A, (2) Meeting the needs of human nature, (3) Protecting the occupants of transmission of infectious diseases that have water supply, waste disposal infrastructure and sewerage regular and eligible health and (4) Protecting the occupants of the possibility of accidents and fire hazards, strong foundation of the house, toxicity free, and even from the threat of traffic accidents (Sanropie, 1992; Anwar, 1996).

From the stance of Islam, translated as residential housing concept that characterized Islam when it was established on the basis and aims to encourage comprehensive Islamic way of life and can be practiced. Features such as outdoor ornaments, domes, the verses of Al-Quran or Islamic geometric motifs are not the only criteria that will make the design of a dwelling house were "unIslamic" or not. But there are some other aspects. Among the aspects emphasized in Islam housing concept are; (1) The existence of a clear boundary between the living room and family room, so "privacy" can be guaranteed and can be maintained especially by the women. While each bedroom can be access by women without having to go through the main sections of the house, (2) The existence of two ways in and out, one for adults and another specifically for residents, especially women, (3) The need for a sheltered space for women doing outdoor activities without causing any discomfort, (4) Orientation houses built must take into account the direction so as to provide maximum space for prayers in congregation and avoid activities in a bathroom can be done with respect for the direction, (5) Each family home has a minimum recommended three bedrooms. On the hadith of Muhammad S.A.W. relating to isolate bed (boys and girls), this three-bedroom home is a necessity for the people. This is based on the hadith of the Prophet which commands its followers to detach bedroom between the sons and daughters when they reached 10 years old, (6) There is a sheltered space for women, work space and interaction for women and the position and orientation of restrooms, (7) The concept of Islamic style housing also urged local authorities are responsible for approving the application development encourages developers to integrate features based on the Islamic way of life in the design of a house (Buang, 2004).

Therefore, home ownership should be based on a sound understanding of the people affected as with the principles of respect, protection and fulfillment of the rights of their needs. The rights include the right to social, cultural rights, and economic rights. Thus, a strategy needs to be formulated and welfare of the people and held in its strategy to increase homeownership rates for middle-income earners in the state of Penang, especially in the Northeast and Southwest regions.

\section{Housing Need}

Housing is a need to most of the peoples. In this, social welfare, social development, and home ownership is very important so that each individual or family can have a decent home to live in a shelter and in accordance with human values (Sirat et al., 1999; Razali Agus, 2001; Mahamud \& Hussein, 2002; Aini Haji Idris \& Siwar eds., 2003; Md Sani @ Abd Rahim, 2007; dan Tan, 2008). In building a house, legislation, policies and programs aimed and need to be look on at housing development to enhance the capacity of human dignity and social functioning (the people) and delegated prosperity for all, especially those individuals or families who are unable in home ownership. In the long run (from time to time) it should be a responsibility of the policy formulation and implementation of programs to provide a home for the disabled in accordance with the conditions and requirements. Thus, the issues related to the housing for middle-income earners in 
Penang, Malaysia can be seen as follows:

First, home ownership numbers for many middle-income earners are still not at satisfactory level based on the standard of living in Malaysia, especially in Penang. In general, the provision of housing by the private sector already meet the needs of high-income groups ie. RM8,000/month (\$2580/month) and above. This assertion is supported by Mr. Stuart MacDonald, Director of Urban and Environment, Penang Institute (oral, January 9, 2013). This situation is driven by the market price of a house in Penang where it is a way too expensive compared to market price of a house in other states in Malaysia. According to the Valuation and Property Services Department of the State of Penang, the price of a two-storey terrace house in Penang (in the North East and South West) in 2009, the cheapest priced is at around RM598,880.00, while the three-storey semi-detached houses priced around $\mathrm{RM} 1,318,880.00$ to $\mathrm{RM} 1,762,000.00$. Minimum price bungalow sold in 2008 and 2009 is $\mathrm{RM} 1,516,250.00$. The apartment and condominiums built for sale at prices ranging from RM185,000.00 to RM761,000.00 per unit. In addition, in the first quarter of 2014, there was no decline in terms of house prices. In fact, the responsible party has recorded the sharp increase in home prices.

Table 1: Home Market Price by Districts in Penang in 2009 and 2014 (Q1)

\begin{tabular}{|c|c|c|}
\hline District & Type of House & $\begin{array}{l}\text { Average Price (RM) } \\
2009 / 2014 \text { (Q1) }\end{array}$ \\
\hline & Two-story terrace & $598,880 / 752,387$ \\
\hline \multirow[t]{4}{*}{ BARAT DAYA } & Three-story terrace & $1,318,880 / 887,000$ \\
\hline & Low Cost Flat & $42,000 / 78,501$ \\
\hline & Condo/ Apartment & $185,000 / 481,250$ \\
\hline & Three-story terrace & $813,000 / 896,000$ \\
\hline \multirow[t]{3}{*}{ TIMUR LAUT } & Three-story semi-D terrace & $1,762,000 / 1,788,311$ \\
\hline & Town house & $728,000 /-$ \\
\hline & Condo/ Apartment & $517,000 / 662,667$ \\
\hline SEBERANG PERAI UTARA & Two-story terrace & $270,500 / 301,500$ \\
\hline \multirow[t]{2}{*}{ SEBERANG PERAI TENGAH } & 2.5 story terrace & $348,000 / 616,353$ \\
\hline & Two-story terrace & $380,000 / 340,513$ \\
\hline \multirow[t]{3}{*}{ SEBERANG PERAI SELATAN } & 2 - 3 story terrace semi-D & $328,000 / 417,527$ \\
\hline & 2 - 2.5 story terrace semi-D & \\
\hline & & $600,000 / 333,904$ \\
\hline
\end{tabular}

Source: 1. Penang Property Assessment and Services Department 2009 and Property Stock Report. 2. National Property Information Center (NAPIC), 2014.

The effectiveness of the current policies set out by the Penang State Government, 'One Family, 
One Home' which was introduced on 14th December 2013 and the policy of 'Building People's Housing', which covers at least 18,000 units of affordable housing through the implementing agency Penang Development Corporation (PDC) is seen with no minimum positive impact on middle-income earners. This is seen by an application to have a house managed by the Penang State Housing Division and PDC keep on increasing from year to year (Officer of the Housing Division of the State of Penang, oral, March 24, 2014). Furthermore, according to Assistant Administrative Officer Housing Unit State of Penang, housing ownership is dominated only by a number of high-income earners (Oral, January 11, 2013). Relatively, it will lead to unhealthy property business activities too. If this situation did not being addressed, it is feared that it will lead to the changes of landscape of the original Penangaite, especially the middle incomers doubtless will be marginalized and squeezed by rapid residential development that only emphasizes luxury home buyers.

In addition, program for middle-income earners in Penang are at alarming. Currently, the National Housing Policy (DRN) and the Penang State Housing Policy is focused on the low-incomers. The DRN policy developed by the Ministry of Housing and Local Government (the ministry) at the beginning of 2013 on Core 1 is "Provision of Adequate Housing By Special Requirements Those who need it". In Penang, the average income of Penangaite (RM5,993 year 2014) is above of national average income where it is at RM4,585 (2014). So in this, it seems that the national policy does not applicable to be match up in Penang as in specific.

Nevertheless, the issue of urban poverty has attracted the people of Penang and also researchers in recent years. Issues on housing in big cities, included Penang is not something unusual emblazoned on the major newspapers front page, forums and scientific conferences at national level. According to Bernama (2012), The Trade Union Congress in the Civil Service (Cuepacs) found that about 60 percent of middle-income civil servants unable to own a house ownership near to their workplace in large cities. Beside, only in rural areas offers such affordable homes priced not exceeding Rm300,000, while many civil servants working in the city (Yatim, 2012). This situation drives most middle-income civil servants had only afford to rent or occupying low cost housing apart from alternatives to occupy government housing (quarters) are extremely limited (Bernama, 2012).

Essentially, there is no documented research done (to date) on home ownership for middleincome earners in Penang with problematic situations, especially in the Northeast and Southwest regions from the point of view of social work knowledge and input. Therefore, a study is important and relevant to the current situation to get a true picture of the problems and issues of the target groups, service systems, policies and existing programs to take place and the importance of the need to be implemented in order to increase home ownership rates for moderate income earners in Penang.

\section{Social Work Perspective}

On the other hand, from the perspective of social work, the issue of home ownership for the middle-income group is closely related to the social structure, coping strategies, and social work practice in the housing settings. Intervention model in this study is important in enhancing the ability to solve problems and overcome, also correlates with providing system resources, services, and opportunities to promote effective operations, and thus contribute to the development and improvement of social policy (Pincus \& Minahan, 1973), particularly on the issue of home ownership 
for middle-income earners in the state of Penang.

Moreover, there are various roles that can be adapted by the social worker in housing settings. Housing social workers involve themselves at the grassroots level of a community organization and capable of acting in a process of economic development, unity organization, and investigation of a policy. However, a housing social worker is required to be equipped and possess a wide range of knowledge relating to housing, skill as a professional social worker and possessing defined values as a social worker.

To equip himself as an authoritative social worker, one must first equip himself with a holistic social work of science. Thus, the role of social workers can generally be expressed briefly in the following phrases:

"...most of us have a pretty good idea of what we what we expect from a doctor or a teacher. For social work, the role expectations are not quite as clearly understood by the general public. Perhaps this is because there are so many professional roles in social work. The number and diversity of social work roles provide opportunity for a great deal of creativity in practice..." (Suppes \& Cressey Wells, 2003, pp. 33)

In addition, social workers in housing settings are also often involved as trainers and facilitators in serving information as well as driving clients or communities to resources and how to develop certain skills. Housing social workers are capable of developing knowledge on housing ownership such as budgeting, discipline, effective communication, diagnosis of thinking, and skills in choosing an area. In this role, residential social workers participated in focus group discussion (FGD) together with clients for various purposes including community development, self-advocacy, political organization, and policy change. In the meantime, social workers in housing settings are also involved in group therapy and leaders especially in developing client cognitive development.

\section{Corresponding Author}

Y.M. Haizzan

Social Work Section, School of Social Sciences, Universiti Sains Malaysia, 11800 Minden, Penang Malaysia.

Email:m_haizzan@usm.my

\section{References}

Said, A. M. (2003). Prosedur Dan Pelaksanaan Penilaian Dampak Sosial. Dlm. Mohd Razali Agus. (pnyt.). Penilaian Dampak Sosial. Kuala Lumpur: Utusan Publications.

Buang, A. H. (2004). Fatwa di Malaysia. Kuala Lumpur. Jabatan Syariah dan Undang-Undang, APIUM.

Aini Haji Idris, N. \& Siwar, C. [eds]. (2003). Kemiskinan Bandar dan Sektor Tidak Formal di Malaysia. Selangor: Penerbit UKM (Universiti Kebangsaan Malaysia).

Azwar, A. (1996). Pengantar Ilmu Kesehatan Lingkungan. Jakarta : Mutiara Sumber Widya.

Bernama. (2012). Ramai penjawat awam tidak mampu miliki rumah sendiri - CUEPACS. Retrive from: 
INTERNATIONAL JOURNAL OF ACADEMIC RESEARCH IN BUSINESS AND SOCIAL SCIENCES

Vol. 8, No. 9, Sept. 2018, E-ISSN: 2222-6990 (C) 2018 HRMARS

http://cuepacs.blogspot.com/2012/05/ramai-penjawat-awam- tidak -mampu-miliki.html.

Siwar, C. (1994) "Poverty Profile in Malaysia: Findings from Ten Districts in

Peninsular Malaysia", dalam Jamilah Arifin (eds.) Poverty Amids Plenty, Pelanduk Publication, Petaling Jaya.

Holman, R. (1978): Poverty: Explanation of Social Deprivation. London: Martin Robertson.

Dora, M. T. (2000). Peminggiran Sosial: Keluarga Melayu Termiskin Bandar, Skudai, Johor Darul Ta'zim. Universiti Teknologi Malaysia Publication.

Narayan-Parker, D. (1997). Voices of the poor: poverty and social capital in Tanzania (Vol. 20). World Bank Publications.

Pincus, A. \& Minahan, A. (1973) Social Work Practice, Peacock, Itasca.

Zin, R. M. (2002). The Financial Crisis and Its Impact on Poverty and Inequality in Malaysia. Institute of Malaysian International Studies. Working Paper.

Razali Agus, M. (2001). Perumahan Awam di Malaysia: Dasar dan Amalan. Kuala Lumpur: Utusan Publications and Distributors Sdn. Bhd.

Sanropie, D. (1992). Pedoman Bidang Studi Perencanaan Penyehatan Lingkungan Pemukiman. Jakarta : Departemen Kesehatan R.I.

Suppes, M. and Cressy Wells, C. (2003). The Social Work Experience: An Introduction to Social Work and Social Welfare. McGraw-Hill Humanities/ Social Sciences/ Languages, New York, New York.

Townsend, P. (1979). Poverty in United Kindom. Penguin Books Ltd. Middlsex.

Yatim, N. (2012). Tangani kenaikan harga rumah. Utusan Malaysia. Retrive from: http://www.utusan.com.my/utusan/Rencana/20120921/re 06/Tangani-kenaikan- hargarumah. 